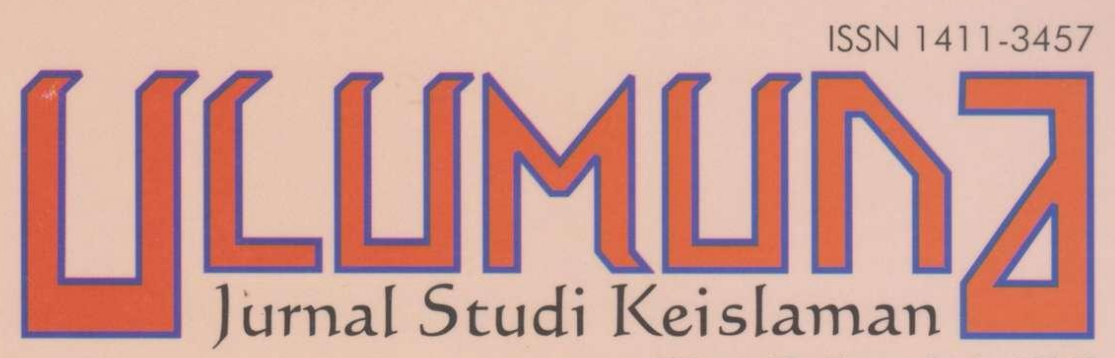

Volume 16 • Nomor 1• Juni 2012

METOdOLOGI PENEMUAN HUKUM ISLAM Munawir Haris

Pembaruan Metode Penemuan HukUm IsLam: PENDEKATAN TERPADU HUKUM ISLAM DAN SOSIAL Moh. Lutfi Nurcahyono TIPOLOGI PEMIKIRAN HUKUM ISLAM: PERgULATAN PEMIIIRAN DARI TRADISIONALIS HINGGa LIBERALIS Muhammad Harfin Zuhdi PEMBARUAN MAȘLAHAHAH DALAM MAQĀSİD AL-SHARI'AH: TELAAH HUMANISTIS TENTANG AL-KULLIYYĀT AL-KHAMSAH Zaenuddin Mansyur

MENUJU HUKUM ISLAM YANG INKLUSIF-HUMANISTIS: ANALISIS PEMIKIRAN JASSER AUDA TENTANG MAQĀSİD AL-SHARI'AAH Muhammad Salahuddin ARAH PEMBARUAN HUKUM WAKAF INDONESIA Miftahul Huda HUKUM ISLAM DALAM TRADISI LOKAL: TelaAh PEMIKIRAN TGH. M. SOleh Chambali tentang HaJI Adi Fadli Panorama Poligami dan Resistensi Perempuan DI LANGSA ACEH Muhammad Ansor PENDEKATAN HUKUM ISLAM TERHADAP JIHAD DAN TERORISME Lukman Arake 



\section{DAFTAR ISI}

\section{Pedoman Transliterasi}

1-20 • Munawir Haris, "Metodologi Penemuan Hukum Islam"

21-40 • Moh. Lutfi Nurcahyono, "Pembaruan Metode Penemuan Hukum Islam: Pendekatan Terpadu Hukum Islam dan Sosial"

41-70 • Muhammad Harfin Zuhdi, "Tipologi Pemikiran Hukum Islam: Pergulatan Pemikiran dari Tradisionalis Hingga Liberalis"

71-102 • Zaenuddin Mansyur, "Pembaruan Maslaḥah dalam Maqāṣīd al-Sharī'ah: Telaah Humanistis tentang al-Kulliyyāt al-Khamsah"

103-124• Muhammad Salahuddin,

"Menuju Hukum Islam yang Inklusif-Humanistis:

Analisis Pemikiran Jasser Auda tentang

Maqāṣīd al-Sharī'ah"

125-142 • Miftahul Huda,

"Arah Pembaruan Hukum Wakaf Indonesia"

143-162 • Adi Fadli,

"Hukum Islam dalam Tradisi Lokal:

Telaah Pemikiran TGH. M. Soleh Chambali tentang Haji"

163-188 • Muhammad Ansor,

"Panorama Poligami dan Resistensi Perempuan di Langsa Aceh"

189-222 • Lukman Arake, "Pendekatan Hukum Islam terhadap Jihad dan Terorisme"

\section{LAMPIRAN- LAMPIRAN}




\section{PEDOMAN TRANSLITERASI}

\begin{tabular}{|c|c|c|c|c|c|c|}
\hline 1 & $=$ & a & & $\dot{\varepsilon}$ & $=$ & $\mathbf{g}$ \\
\hline ب & $=$ & $\mathbf{b}$ & & ف & $=$ & f \\
\hline$ت$ & $=$ & $\mathbf{t}$ & & ق & $=$ & $q$ \\
\hline ث & $=$ & th & & ك & $=$ & $\mathbf{k}$ \\
\hline ج & $=$ & $\mathfrak{j}$ & & J & $=$ & 1 \\
\hline$\tau$ & $=$ & hạ & & b & $=$ & $\mathrm{m}$ \\
\hline$\dot{\tau}$ & $=$ & $\mathbf{k h}$ & & $\dot{ن}$ & $=$ & $\mathbf{n}$ \\
\hline د & $=$ & $\mathrm{d}$ & & 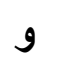 & $=$ & $\mathbf{w}$ \\
\hline j & $=$ & dh & & $\bullet$ & $=$ & $\mathbf{h}$ \\
\hline J & $=$ & $\mathbf{r}$ & & $\varepsilon$ & $=$ & , \\
\hline j & $=$ & $\mathbf{z}$ & & ي & $=$ & $\mathrm{y}$ \\
\hline س & $=$ & $\mathbf{s}$ & & & & \\
\hline 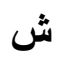 & $=$ & sh & \multicolumn{4}{|c|}{ Untuk Madd dan Diftong } \\
\hline ص & $=$ & ș & i & $=$ & \multicolumn{2}{|c|}{$\bar{a}$ (a panjang) } \\
\hline 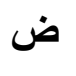 & $=$ & d & إي & $=$ & \multicolumn{2}{|c|}{$\overline{1}$ (i panjang) } \\
\hline b & $=$ & $\underline{t}$ & 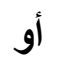 & $=$ & \multicolumn{2}{|c|}{$\bar{u}$ (u panjang) } \\
\hline ظ & $=$ & $\mathbf{z}$ & 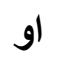 & $=$ & \multicolumn{2}{|c|}{ aw } \\
\hline$\varepsilon$ & $=$ & 6 & 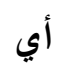 & $=$ & \multicolumn{2}{|l|}{ ay } \\
\hline
\end{tabular}

Contoh penulisan dengan transilterasi:

اعوذ بالله من الشيطان الرجيم (a'üdhu bi al-Lāh min al-shaytān al-rajìm);

بسم الله الرحمن الحيم (bism al-Läh al-rahmān al-rahìm);

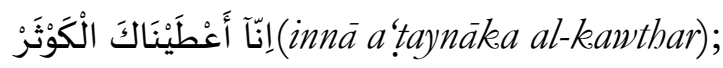

هَصََلِّ لِربِّكَ وَانْحَرْ (fasalli lirabbika wanhar);

صباح الخير (sabāh al-khayr). 


\title{
METODOLOGI PENEMUAN HUKUM ISLAM
}

\author{
Munawir Haris \\ Jurusan Dakwah STAIN Sorong, Papua Barat \\ Email: irfani.fanani@gmail.com)
}

Abstract: Continuous dialogue between Islamic law and its context of space and time necessitates the emergence of various methods of invention of Islamic law. This paper aims to map the diversity of the methods under some categorizations. The authors found that, at least, there are three models of methods of Islamic law invention, namely linguistic interpretation, causation, and adjustment. All are so strong in their trend of textual understanding of Islamic law that they potentially bring out epistemological problem, such as the law construction which is too idealistic so that it be not applicable, or vice versa. In that context, Safi offers a method of law invention called "integrated" model which is discovery-oriented blending of textual (normative-textual) and contextual analysis (social-empirical), so that Islamic law does not lose its relevance in the context contemporary society today.

Abstrak: Dialog berkelanjutan antara bukum Islam dengan konteks ruang dan waktunya meniscayakan munculnya aneka metode penemuan bukum Islam. Tulisan ini bertujuan untuk memetakan keragaman metode itu dengan melakukan kategorisasi-kategorisasi. Penulis menemukan bahwa, paling tidak, terdapat tiga model metode penemuan bukum Islam, yaitu interpretasi linguistik, kausasi, dan penyelarasan. Tiga metode itu sangat kuat kecenderungan tekstualitasnya sehingga berpotensi memunculkan problem epistemologik di kalangan umat Islam, seperti adanya konstruksi hukum yang terlalu idealis dan tidak aplikatif, atau sebaliknya. Dalam konteks itu, tawaran Safi tentang metode penemuan bukum "terpadu" sangat menarik untuk dicermati sebagai suatu model penemuan bukum yang berorientasi pada perpaduan antara analisis teks (normatif-tekstual) dan konteks (sosial-empiris), sehingga hukum Islam tidak kehilangan relevansinya dalam konteks masyarakat kontemporer dewasa ini.

Keywords: metode penemuan hukum, ruang dan waktu, normatif-tekstual, sosial-kontekstual, relevansi bukum. 
HUKUM Islam, disamping sarat dengan muatan sosiologis, tidak dapat dipungkiri pula memiliki dimensi teologis. Penempatan cara pandang yang keliru terhadap dimensi teologis yang dikandungnya mengakibatkan anggapan bahwa fiqh merupakan aturan yang sakral, harus diterima apa adanya (take for granted), bahkan dalam keadaan tertentu, orang akan merasa takut melakukan evaluasi terhadap aturan-aturan fiqh yang ada. Logika tersebut secara psikologis sudah terbebani oleh nilai-nilai kesakralan fiqh. Diperlukan satu kajian yang mampu mengantarkan kepada cara pandang yang benar mengenai aspek teologis dalam fiqh. Artinya metode hukum Islam harus ditemukan dengan sumber yang otentik, bebas dari bias-bias yang mengitarinya.

Hukum Islam adalah sekumpulan aturan keagamaan, totalitas perintah Allah yang mengatur perilaku kehidupan umat Islam dalam keseluruhan aspeknya. ${ }^{1}$ Pengertian tersebut menunjukkan bahwa hukum Islam adalah pondasi yang ditetapkan Allah atas seluruh aktifitas umat Islam. Menurut para ahli Ușūl fiqh, hukum Islam merupakan instruksi-wacana (khițāb) Allah kepada para hamba-Nya. Sebagai khitäb, manusia "hanya" bertugas mengenali dan menemukannya melalui tanda-tanda yang diberikan Allah. Dengan kata lain, hukum shariah merupakan man-discovered law dan bukan man-made law. ${ }^{2}$ Hal ini, tampak dalam ungkapan Coulson, Tuhan yang merencanakan, namun manusia yang memformulasikannya. ${ }^{3}$ Dengan demikian dapat dipahami, bahwa hukum tidak selalu merupakan barang siap pakai, melainkan harus dicari dan ditemukan. Oleh karena itu, penemuan hukum merupakan suatu hal yang inheren dalam setiap sistem hukum, termasuk hukum Islam. ${ }^{4}$

${ }^{1}$ Josept Schacht, An Introduction to Islamic Law (London: Oxford University Press, 1971), 1.

2Syamsul Anwar, "Epistemologi Hukum Islam", dalam Syamsul Anwar, Metodologi Hukum Islam (Kumpulan makalah tidak diterbitkan), 113.

${ }^{3}$ Noel J. Coulson, Konflik dalam Yurisprudensi Islam, ter. Fuad (Yogyakarta: Navila, 2001), 2.

${ }^{4}$ Baca, Syamsul Anwar, "Teori Konformitas dalam Metode Penemuan Hukum Islam al-Gazali” dalam Antologi Studi Islam: Teori dan Metodologi, ed. M. Amin Abdullah, dkk (Yogyakarta: Sunan Kalijaga Press, 2000), 273. 
Di sisi lain, keharusan menemukan hukum sangat terkait dengan adanya perubahan dan perkembangan peradaban manusia. Seringkali didapati banyak peristiwa yang tidak terespon secara jelas dalam teks yang merupakan dialog Allah dengan manusia. Hal ini sesuai dengan ungkapan para pakar ahli hukum Islam, Al-Nușuss Mutanāhiyah wa Al-Waqäì Gayr Mutanăhiyah. ${ }^{5}$ Dengan demikian, ijtihad yang merupakan prinsip gerak (the principle of movement) dalam struktur Islam harus dilakukan untuk menemukan konstruksi hukum atas realitas yang muncul. ${ }^{6}$ Hal tersebut kemudian mendorong para ahli hukum Islam untuk mencari dan merumuskan metode-metode penemuan hukum. Aneka metode hasil rumusan para pakar tersebut, kemudian dijadikan pegangan dan acuan untuk mencari rumusan hukum terkait dengan kasus-kasus yang terjadi di masyarakat.

Tulisan ini berupaya mendeskripsikan beberapa point penting, yakni: Pertama, sekilas gambaran metode penemuan hukum. Kedua, jenis metode penemuan hukum Islam. Ketiga, metode penemuan hukum Islam; sebuah tawaran positif dari seorang cendikiwan Islam dalam bidang hukum, yakni Safi. Keempat, kesimpulan; suatu refleksi dari metode yang ditawarkan oleh Safi dalam dunia Islam. Rekonstruksi metode penemuan hukum dalam konteks Islam menjadi penting hukum Islam dari masa ke masa pada dasarnya seringkali bertolak dari adanya gap antara konstruksi hukum dengan aplikasinya di lapangan.

\section{Sekilas Gambaran Metode Penemuan Hukum}

Metode penemuan hukum merupakan suatu proses individualisasi dan kongkretisasi peraturan-peraturan umum dengan mengaitkannya kepada peristiwa-peristiwa atau kasuskasus tertentu. Dengan demikian, penemuan hukum bersifat klinis, tujuannya adalah untuk menjawab pertanyaan apa hukum atas suatu kasus tertentu tersebut? Penemuan hukum

5Syamsul Anwar, "Argumen A Fortiori dalam Metode Penemuan Hukum Islam" dalam Syamsul Anwar, Metodologi Hukum Islam (Kumpulan makalah tidak diterbitkan), 45.

${ }^{6}$ Muhammad Iqbal, Pembangunan Kembali Alam Pikiran Islam, ter. Osman Raliby (Jakarta: Bulan Bintang, 1983), 204. 
(rechtsvinding) memiliki perbedaan dengan penelitian hukum (rechtsonderzoek). ${ }^{7}$ Penelitian hukum berusaha menyelidiki hukum sebagai suatu fenomena sosial dengan mempelajari hubungannya dengan fenomena sosial lainnya, baik sebagai variabel independen yang mempengaruhi masyarakat, maupun sebagai variabel dependen yang dipengaruhi oleh perubahan-perubahan masyarakat. Di samping itu, penelitian hukum juga melakukan penyelidikan normatif terhadap hukum untuk melakukan inventarisasi peraturan hukum, menemukan asas-asasnya (doktrin hukum), meneliti taraf sinkronisasi dan sistematisasi hukum serta menemukan hukum untuk menyelesaikan suatu perkara in concreto. Dengan demikian, penemuan hukum (rechtsvinding) hanyalah sebagian dari penelitian hukum (rechtsonderzoek). ${ }^{8}$

Metode penemuan hukum tidak hanya dikenal dalam konstelasi hukum Islam, tetapi dalam hukum Barat pun jauh lebih maju. Akan tetapi, para ahli hukum Barat lebih menyukai penggunaan istilah pembentukan hukum dari pada istilah penemuan hukum. Dalam hukum Barat, seorang hakim yang bertindak selaku pembentuk hukum dalam hal perundangundangan tidak menyebutkan sesuatu ketentuan untuk menyelesaikan suatu perkara yang terjadi. Hakim memiliki kekuatan pembentuk hukum, namun kedudukan hakim bukanlah pemegang kekuasaan legislatif. Oleh sebab itu, keputusan hakim tidak mempunyai kekuatan hukum yang berlaku seperti peraturan umum lainnya. Dengan demikian, keputusan hakim hanya berlaku kepada pihak-pihak yang bersangkutan saja. ${ }^{9}$

Dalam dunia Islam, dari sekian banyak pola pemikiran Islam yang bercorak pembaruan tentu berimplikasi pada aspek hukum Islam, baik secara metodologis maupun wacana. Oleh karena itu, metode pembaruan hukum Islam bukanlah sebuah metode yang terlepas dari pembaruan pemikiran. Hal tersebut perlu pelacakan yang cermat karena tidak semua tokoh mempunyai perhatian

${ }^{7}$ Syamsul Anwar, "Teori..., 274.

${ }^{8}$ Ibid.

${ }^{9}$ Baca, C.S.T Kansil, Pengantar Ilmu Hukum dan Tata Hukum Indonesia (Jakarta: Balai Pustaka, 1989), 65. 
yang khusus terhadap hukum Islam. Terlebih lagi, bila ditarik ke dalam wilayah hukum keluarga muslim khususnya, dibutuhkan upaya penyesuaian, bahkan modifikasi terhadap teori-teori pemikiran yang ditawarkan para tokoh yang berkaitan dengan hukum Islam.

Dalam sejarah perkembangan hukum Islam di dunia Sunni, Al-Risālah karya Al-Shafíi dianggap buku rintisan pertama tentang Ușūl fiqh. Penulisannya bercorak teologis deduktif yang kemudian diikuti oleh para ahli ushul mazhab mutakallimun (Shafi'iyah, Malikiyah, Hanabilah dan Mu'tazilah). Setelah kurang lebih lima abad (dari abad ke-2 H. sampai 7 H.) baru mengalami perbaikan dengan munculnya Al-Shätibi (w.1388 M.) yang menambahkan teori Maqūshìd al-Sharìah yang mengacu pada maksud Allah yang paling mendasar sebagai pembuat hukum. Enam abad kemudian sumbangan Al-Shätibì direvitalisasikan lagi oleh para pembaharu Ușūl fiqh, seperti Muhammad Abduh (w. 1905 M.), Rashid Rị̣a (w. 1935 M.), Abdul Wahab Khallaf (w. 1956 M.), Allal al-Fasi (w. 1973 M.) dan Hasan Turabi. Karena tidak menawarkan teori baru, kecuali merevitalisasi prinsip mașlahah (kebaikan) yang ditawarkan Al-Shạtibi melalui teori maqāsìd-nya, Weil B. Hallaq mengkategorikan para pembaharu di bidang ushul tersebut ke dalam kelompok pembaharu penganut utilitarianisme.

Sementara itu, pertanyaan tentang bagaimanakah teks suci dapat dipahami dan kemudian dijalankan dalam konteks dunia modern yang tentunya tidak lagi sama dengan konteks zaman Nabi belumn terjawab. Pernyataan semacam itu, menurut sebagian pakar seperti Muhammad Iqbal, Mahmud Muhammad Taha, Abdullah Ahmed An-Naim, Muhammad Said Ashmawi, Fazlur Rahman, dan Muhammad Syahrur, sama sekali tidak dapat diselesaikan dengan berpijak pada prinsip maslahah klasik di atas. Mereka beranggapan prinsip maslaḩah tidak lagi memadai untuk membuat hukum Islam tetap relevan di dunia modern. Weil B. Hallaq menamakan kelompok ini dengan aliran liberalisme keagamaan karena cenderung berdiri pada paradigma yang terlepas dari pada paradigma klasik. ${ }^{10}$

${ }^{10}$ A. Khudori Sholeh (ed), Pemikiran Islam Kontemporer (Yogyakarta, Jendela, 2003), 5. 
Dalam perjalanan sejarahnya, hukum Islam merupakan suatu kekuatan yang dinamis dan kreatif. Hal ini dapat dilihat dari munculnya sejumlah mazhab hukum yang memiliki corak masing-masing sesuai dengan latar belakang sosiokultural dan politik di mana mazhab hukum itu tumbuh dan berkembang. ${ }^{11}$ Perkembangan yang dinamis dan kreatif ini setidaknya didorong oleh tiga faktor utama: Pertama, dorongan keagamaan. Islam merupakan sumber norma dan nilai normatif yang mengatur seluruh aspek kehidupan kaum muslimin, maka kebutuhan untuk membumikan norma, dan nilai atau pun mengintegrasikan dalam kehidupan kaum muslim, selalu muncul ke permukaan. Demikian halnya dengan hukum Islam itu sendiri, dimana ia merupakan kebutuhan pokok masyarakat muslim. Kedua, dengan meluasnya domain politik Islam pada masa khalifah 'Umar, maka terjadi pergeseran-pergeseran sosial yang pada gilirannya menimbulkan sejumlah besar problem baru yang berhubungan dengan hukum Islam. Ketiga, independensi para pakar hukum Islam dari kekuasaan politik. Kemandirian ini telah menyebabkan mereka mampu mengembangkan pemikiran hukum, tanpa mendapat rintangan, selaras dengan pemahaman mereka masing-masing.

Menurut Hasbi Al-Shiddiqiey, dalam paradigma Ușūl fiqh klasik terdapat paling tidak lima prinsip yang memungkinkan hukum Islam bisa berkembang mengikuti zaman. Prinsif tersebut adalah: 1) Prinsip Ijma; 2) Prinsip Qiyas; 3) Prinsip Maslabah Mursalab; 4) Prinsip memelihara Urf; dan 5) Prinsif berubahnya hukum dengan berubahnya masa. Kelima prinsip tersebut dengan jelas memperlihatkan betapa fleksibelnya hukum Islam. Dengan berlalunya waktu dan tempat, perkembangan hukum Islam yang dinamis dan kreatif pada masa awalnya kemudian menjelma ke dalam bentuk mazhab-mazhab yang masyhur di kalangan masyarkat Islam sendiri.

Dengan terjadinya kristalisasi pada mazhab-mazhab tersebut, hak untuk berijtihad mulai dibatasi dan pada gilirannya dinyatakan tertutup oleh para ulama yang fanatik dengan guru mereka sebelumnya. Akibatnya, terjadi semacam konsensus

${ }^{11}$ Ibid. 
bahwa tidak seorang pun yang boleh mengklaim memiliki kualifikasi untuk melaksanakan ijtihad mutlak. Jadi secara teoritis, ijtihad memang tidak dinyatakan tertutup, tetapi kualifikasinya yang diformat sedemikian rumit. ${ }^{12}$

\section{Jenis Metode Penemuan Hukum Islam}

Sebagaimana dijelaskan sebelumnya, bahwa hukum Islam merupakan sapaan (khitäb) Allah. Posisi manusia hanya bisa mencari dan menemukannya. Hal tersebut kemudian mendorong pada perkembangan metode-metode penemuan hukum Islam. Dalam sejarah, dikenal banyak metode penemuan hukum. Medode-metode paling tidak dapat diklasifikasikan menjadi tiga model, yaitu metode interpretasi linguistik, metode kausasi, dan metode penyelarasan. ${ }^{13}$ Berikut penjelasan selengkapnya.

Metode pertama, yakni metode interpretasi linguistik merupakan metode penemuan hukum yang beroperasi dengan melakukan interpretasi terhadap teks-teks al-Qur'an dan hadis. Dengan demikian, metode linguistik digunakan terkait dengan kasus-kasus yang sudah ada teks hukumnya, namun teks hukum tersebut masih kabur (tidak jelas), karena di dalamnya terdapat ayat-ayat hukum yang mutashäbih. Pola kajian yang digunakan dalam metode intepretasi linguistik menghasilkan empat taksonomi pernyataan hukum dari teks-teks hukum, yaitu: Pertama, dari segi tingkat kejelasannya. Kedua, dari segi polapola penunjukkan kepada hukum yang dimaksudkan. Ketiga, dari segi luasan maupun sempitnya cakupan pernyataan hukum. Keempat, dari segi bentuk-bentuk formula taklif dalam pernyataan. ${ }^{14}$

Dalam taksonomi pertama, metode interpretasi linguistik meneropong pada tingkat kejelasan sebuah teks. Dari hal ini, kemudian berimplikasi pada munculnya dua kategori baru, yaitu teks pernyataan hukum yang jelas dan teks pernyataan hukum yang tidak jelas. Teks pernyataan hukum yang jelas dapat

${ }^{12}$ Taufiq Adnan Amal, Islam dan Tantangan Modernitas: Studi Atas Pemikiran Hukum Fazlur Rahman (Bandung: Mizan, 1989), 33-5.

${ }^{13}$ Syamsul Anwar, "Teori ..., 275.

${ }^{14}$ Ibid. 
dibedakan menjadi zāhir, nāṣs, mufassar dan muḅkam. Sedangkan teks pernyataan hukum yang tidak jelas dapat dibedakan menjadi khäfí, mushkil, mujmāl dan mutashäbih. Perbedaan mendasar dari kategori yang jelas (wadih) dan tidak jelas (mubham) adalah bila yang terakhir dalam mencapai kejelasan membutuhkan qarinah (petanda) eksternal maka yang pertama dapat dijelaskan dengan menganalisis teks itu sendiri. Tingkat kejelasan dalam masingmasing dan antar kategori-kategori itu berkaitan dengan luasnya analisis tekstual (atau eksplikasi) yang dibutuhkan. Berikut tabel dari implikasi penjelasan di atas:

Kategori pernyataan hukum yang jelas menurut mazhab Hanafi adalah seperti tertera dalam tabel berikut: ${ }^{15}$

\begin{tabular}{|c|c|c|c|}
\hline Tipe & Definisi & Contoh & Kejelasan \\
\hline Zâbir & $\begin{array}{l}\text { Teks yang } \\
\text { maknanya dapat } \\
\text { dipahami tanpa } \\
\text { petanda (qarinab) } \\
\text { eksternal meskipun } \\
\text { makna yang diacu } \\
\text { bukan makna yang } \\
\text { dimaksud }\end{array}$ & \multirow[t]{2}{*}{$\begin{array}{l}\text { Sesungguhnya } \\
\text { jual beli itu sama } \\
\text { dengan riba, } \\
\text { namun Allah } \\
\text { menghalalkan } \\
\text { jual beli dan } \\
\text { mengharamkan } \\
\text { riba (Qs. [2]: } \\
\text { 275). }\end{array}$} & $\begin{array}{l}\text { Makna zahir teks } \\
\text { itu bahwa } \\
\text { transaksi } \\
\text { komersial } \\
\text { dibolehkan, } \\
\text { kecuali jual beli } \\
\text { yang mengandung } \\
\text { riba }\end{array}$ \\
\hline Nâṣ̣ & $\begin{array}{l}\text { Teks yang } \\
\text { maknanya dapat } \\
\text { dipahami tanpa } \\
\text { qarinah eksternal. } \\
\text { Makna teks adalah } \\
\text { makna yang } \\
\text { dimaksud }\end{array}$ & & $\begin{array}{l}\text { Makna nâș teks } \\
\text { itu adalah tidak } \\
\text { adanya persamaan } \\
\text { antara transaksi } \\
\text { komersial dan } \\
\text { riba. }\end{array}$ \\
\hline Mufassar & $\begin{array}{l}\text { Teks yang } \\
\text { maknanya sangat } \\
\text { jelas sehingga tidak } \\
\text { membutuhkan } \\
\text { penjelasan lebih } \\
\text { lanjut }\end{array}$ & $\begin{array}{l}\text { Perempuan yang } \\
\text { berzina dan laki- } \\
\text { laki yang berzina } \\
\text { maka deralah } \\
\text { tiap-tiap dari } \\
\text { keduanya } 100 \\
\text { kali (Qs. [24]: 2) }\end{array}$ & $\begin{array}{l}\text { Jumlah deraan } \\
\text { yang dikenakan } \\
\text { kepada keduanya } \\
\text { sangat jelas }\end{array}$ \\
\hline Muhkam & $\begin{array}{l}\text { Teks yang } \\
\text { maknanya sangat } \\
\text { jelas sehingga tidak }\end{array}$ & $\begin{array}{l}\text { Allah maha } \\
\text { mengetahui } \\
\text { segala sesuatu }\end{array}$ & $\begin{array}{l}\text { Suatu teks yang } \\
\text { jelas yang } \\
\text { mengungkapkan }\end{array}$ \\
\hline
\end{tabular}

${ }^{15}$ Louay Safi, Ancangan Metodologi Alternatif, Sebuah Refleksi Perbandingan Metode Penelitian Islam dan Barat, ter. Imam Khoiri (Yogyakarta: Tiara Wacana, 2001), 53. 


\begin{tabular}{|c|l|l|l|}
\hline Tipe & \multicolumn{1}{|c|}{ Definisi } & \multicolumn{1}{c|}{ Contoh } & \multicolumn{1}{c|}{ Kejelasan } \\
\hline & $\begin{array}{l}\text { membutuhkan } \\
\text { penjelasan lain dan } \\
\text { tidak dapat } \\
\text { dihapuskan } \\
\text { (nasakh) }\end{array}$ & (Qs. [33]: 40) & $\begin{array}{l}\text { suatu kebenaran } \\
\text { umum yang tidak } \\
\text { dapat dihapuskan }\end{array}$ \\
\hline
\end{tabular}

Kategori pernyataan hukum yang tidak jelas menurut mazhab Hanafi adalah seperti tertera dalam tabel berikut: ${ }^{16}$

\begin{tabular}{|c|c|c|c|}
\hline Tipe & Definisi & Contoh & Kejelasan \\
\hline Khâfî̀ & $\begin{array}{l}\text { Teks, sekalipun } \\
\text { maknanya secara } \\
\text { umum cukup } \\
\text { jelas, namun } \\
\text { membutuhkan } \\
\text { penjelasan } \\
\text { karena acuan } \\
\text { maknanya yang } \\
\text { spesifik }\end{array}$ & $\begin{array}{l}\text { (1) Laki-laki dan } \\
\text { perempuan yang } \\
\text { mencuri } \\
\text { potonglah } \\
\text { tangan keduanya } \\
\text { (Qs. [5]: 38) } \\
\text { (2) Tidak ada } \\
\text { bagian waris bagi } \\
\text { pembunuh } \\
\text { (hadis) }\end{array}$ & $\begin{array}{l}\text { Terdapat } \\
\text { ambiguitas } \\
\text { apakah orang } \\
\text { yang mencuri } \\
\text { uang melalui } \\
\text { penipuan } \\
\text { termasuk pencuri } \\
\text { dalam contoh } 1 . \\
\text { dan apakah } \\
\text { pembunuh } \\
\text { dalam contoh } 2 \\
\text { termasuk mereka } \\
\text { yang membunuh } \\
\text { secara tidak } \\
\text { sengaja. }\end{array}$ \\
\hline Mushkil & $\begin{array}{l}\text { Teks di mana } \\
\text { maknanya tidak } \\
\text { dapat diperoleh } \\
\text { dari ungkapan- } \\
\text { ungkapannya } \\
\text { tanpa qarinah } \\
\text { eksternal }\end{array}$ & $\begin{array}{l}\text { Perempuan- } \\
\text { perempuan yang } \\
\text { ditalak } \\
\text { hendaklah } \\
\text { menahan diri } \\
\text { selama tiga kali } \\
\text { qurú' (Qs. [2]: } \\
228 \text { ) }\end{array}$ & $\begin{array}{l}\text { Istilah qurû' } \\
\text { adalah } \\
\text { homonim, } \\
\text { mustarak dapat } \\
\text { bermakna } \\
\text { periode } \\
\text { menstruasi atau } \\
\text { masa suci. }\end{array}$ \\
\hline Mujmal & $\begin{array}{l}\text { Teks yang } \\
\text { maknanya tidak } \\
\text { dapat diperoleh } \\
\text { dari } \\
\text { ungkapannya, } \\
\text { dan bagi mereka } \\
\text { yang }\end{array}$ & $\begin{array}{l}\text { Sesungguhnya } \\
\text { salat itu adalah } \\
\text { kewajiban yang } \\
\text { ditentukan } \\
\text { waktunya atas } \\
\text { orang-orang } \\
\text { yang beriman }\end{array}$ & $\begin{array}{l}\text { Terma 'salat' } \\
\text { adalah mujmal } \\
\text { yang harus } \\
\text { dijelaskan } \\
\text { dengan mencari } \\
\text { teks-teks penjelas }\end{array}$ \\
\hline
\end{tabular}

16Ibid., 54. 


\begin{tabular}{|c|c|c|c|}
\hline Tipe & Definisi & Contoh & Kejelasan \\
\hline & $\begin{array}{l}\text { memahaminya } \\
\text { tidak menjumpai } \\
\text { qarinah linguistik } \\
\text { atau eksistensial. }\end{array}$ & (Qs. [4]: 103) & \\
\hline Mutashâbih & $\begin{array}{l}\text { Teks yang } \\
\text { maknanya tidak } \\
\text { dapat diperoleh } \\
\text { baik dari } \\
\text { ungkapannya } \\
\text { maupun dari } \\
\text { qarînah-qarinah } \\
\text { eksternal. } \\
\text { Kejelasan } \\
\text { maknanya } \\
\text { membutuhkan } \\
\text { eksplikasi }\end{array}$ & $\begin{array}{l}\text { Tangan Allah } \\
\text { berada di atas } \\
\text { tangan-tangan } \\
\text { mereka (Qs. [48]: } \\
\text { 10). }\end{array}$ & $\begin{array}{l}\text { Terma "tangan" } \\
\text { tidak dapat } \\
\text { dipahami dari } \\
\text { makna literalnya, } \\
\text { karena } \\
\text { bertentangan } \\
\text { dengan prinsip } \\
\text { fundamental ayat } \\
\text { "tidak ada } \\
\text { sesuatu -pun } \\
\text { yang } \\
\text { menyerupai- } \\
\text { Nya". (Qs. [42]: } \\
\text { 11) }\end{array}$ \\
\hline
\end{tabular}

Taksonomi kedua, metode linguistik menyelidiki pada segi pola-pola penunjukkan kepada hukum yang dimaksudkan. Penyelidikan ini kemudian memunculkan empat kategori penunjukan makna (al-dalalab), yaitu: penunjukkan secara ekspresif (dalalah al-ibarah), penunjukkan secara indikatif (dalälah al-ishärah), penunjukkan secara tekstual (dalälah al-nāṣs), dan penunjukkan secara implisit (dalälah al-iqtidā).

Kategori Penunjukan Makna (al-dalälah) menurut Hanafi: ${ }^{17}$

\begin{tabular}{|c|c|c|c|}
\hline Klasifikasi & Definisi & Contoh & $\begin{array}{l}\text { Referensi } \\
\text { (dalâlah) }\end{array}$ \\
\hline $\begin{array}{l}\text { Tbârah } \\
\text { (ekspresif) }\end{array}$ & $\begin{array}{l}\text { Makna yang } \\
\text { diperoleh dari } \\
\text { ungkapan dan } \\
\text { dimaksudkan } \\
\text { oleh tanda - } \\
\text { makna literal }\end{array}$ & $\begin{array}{l}\text { Artikel } 374 \text { kode } \\
\text { penal Mesir } \\
\text { menyatakan } \\
\text { "perempuan } \\
\text { yang telah } \\
\text { menikah yang } \\
\text { menjalani } \\
\text { hukuman karena } \\
\text { zina akan dijatuhi } \\
\text { hukuman penjara }\end{array}$ & $\begin{array}{l}\text { Perempuan yang } \\
\text { telah menikah } \\
\text { yang berzina } \\
\text { dapat dijatuhi } \\
\text { hukam dua tahun } \\
\text { penjara. Suami } \\
\text { dapat } \\
\text { menghentikan } \\
\text { eksekusi } \\
\text { hukuman. }\end{array}$ \\
\hline
\end{tabular}

${ }^{17}$ Ibid., 62. 


\begin{tabular}{|c|c|c|c|}
\hline Klasifikasi & Definisi & Contoh & $\begin{array}{l}\text { Referensi } \\
\text { (dalâlah) }\end{array}$ \\
\hline $\begin{array}{l}\text { Ishârah } \\
\text { (Indikatif) }\end{array}$ & $\begin{array}{l}\text { Makna yang } \\
\text { diinferensikan } \\
\text { dari ungkapan } \\
\text { sekalipun tidak } \\
\text { diungkapkan } \\
\text { atau } \\
\text { dimaksudkan } \\
\text { secara eksplisit }\end{array}$ & \multirow[t]{2}{*}{$\begin{array}{l}\text { maksimal selama } \\
\text { dua tahun. Suami } \\
\text { dapat } \\
\text { membatalkan } \\
\text { eksekusi } \\
\text { hukuman dengan } \\
\text { menyetujui } \\
\text { melanjutkan } \\
\text { hubungan } \\
\text { perkawinan }\end{array}$} & $\begin{array}{l}\text { Perbuatan zina } \\
\text { yang dilakukan } \\
\text { isteri adalah } \\
\text { suatu tindak } \\
\text { kejahatan } \\
\text { terhadap suami, } \\
\text { bukan terhadap } \\
\text { masyarakat. } \\
\text { Hanya suami } \\
\text { yang berhak } \\
\text { menghentikan } \\
\text { pelaksanaan } \\
\text { hukuman }\end{array}$ \\
\hline $\begin{array}{l}\text { Nâșs } \\
\text { (tekstual) }\end{array}$ & $\begin{array}{l}\text { Makna yang } \\
\text { diperoleh dari } \\
\text { kontekstur tapi } \\
\text { tidak dari } \\
\text { ungkapan teks }\end{array}$ & & $\begin{array}{l}\text { Suami dapat } \\
\text { menghentikan } \\
\text { permulaan } \\
\text { berbagai } \\
\text { tindakan hukum } \\
\text { yang dikenakan } \\
\text { terhadap } \\
\text { isterinya yang } \\
\text { berzina, karena } \\
\text { seseorang yang } \\
\text { dapat mencegah } \\
\text { pelaksanaannya } \\
\text { juga dapat } \\
\text { mencegah } \\
\text { prosedur } \\
\text { utamanya }\end{array}$ \\
\hline $\begin{array}{l}\text { Iqtiḍ̂a' } \\
\text { (implisit) }\end{array}$ & $\begin{array}{l}\text { Makna yang } \\
\text { diperoleh dari } \\
\text { teks tetapi hanya } \\
\text { setelah } \\
\text { memasukkan } \\
\text { terma-terma } \\
\text { tertentu yang } \\
\text { meskipun } \\
\text { diasumsikan oleh } \\
\text { tanda, namun ia } \\
\text { diabaikan }\end{array}$ & $\begin{array}{l}\text { Umatku } \\
\text { diampuni karena } \\
\text { melakukan } \\
\text { perbuatan sebab } \\
\text { kekeliruan, lupa } \\
\text { dan di bawah } \\
\text { paksaan (hadis) } \\
\text { Tanyalah kota } \\
\text { negeri yang kami } \\
\text { berada di sana } \\
\text { dan kafilah yang } \\
\text { kami datang } \\
\text { bersamanya (Qs. } \\
\text { [12]: 82) }\end{array}$ & $\begin{array}{l}\text { Umatku } \\
\text { diampuni } \\
\text { dosanya yang } \\
\text { terkait dengan } \\
\text { kekeliruan ..... }\end{array}$ \\
\hline
\end{tabular}


Taksonomi ketiga merupakan penyelidikan metode linguistik dari segi luas-sempitnya cakupan pernyataan hukum. Dari hal ini kemudian ditemukan pernyataan hukum yang bersifat 'amm dan khāșs, mutlaq dan muqayyad, haqiqi dan majāzi, serta mushtarak. Secara singkat, istilah-istilah tersebut mempunyai pengertianpengertian tersendiri, yakni: kata yang bersifat 'amm merupakan kata yang menunjukkan pada jumlah yang banyak dan mencangkup apa saja yang bisa diterapkan kepadanya. ${ }^{18}$ Sedangkan khāṣs merupakan implikasi berlawanan dari 'àmm.

Secara sederhana dapat disimpulkan bahwa kata yang bersifat āmm merupakan kata yang belum spesifik, sedangkan kata yang bersifat khāṣs merupakan kata yang spesifik. Sedangkan mutlaq merupakan kata yang tidak terkualifikasi atau pun terbatas penerapannya, sedangkan muqayyad merupakan kata yang terkualifikasi. ${ }^{19}$ Mutlaq juga dapat didefinisikan sebagai kata yang menunjukkan pada hakekat kata itu apa adanya tanpa memandang jumlah atau pun sifatnya, sedangkan muqayyad merupakan kata yang menunjukkan pada hakikat kata tersebut dengan dibatasi oleh sifat, keadaan, dan syarat tertentu. ${ }^{20}$ Adapun majāri merupakan lafaz yang berbentuk homonim yang mencangkup apa yang diistilahkan sebagai kepalsuan atau ketidakrealistisan. Sebaliknya, haqiqi merupakan lafaz yang maknanya dapat diketahui dari harfiyah-nya. ${ }^{21}$ Sedangkan mushtarak merupakan kata yang menunjukkan pada lebih dari satu makna. ${ }^{22}$

Taksonomi keempat adalah penyelidikan metode linguistik yang ditilik dari segi bentuk-bentuk formula taklif dalam pernyataan. Dari penyelidikan ini ditemukan adanya kategori perintah (amr) dan larangan (nabi). Perintah (amr) dapat

${ }^{18}$ Waḥbah al-Zuhaylī, Ușūl al-Fiqh al-Islāmì, cet.ke-1 (Damaskus: Dār alFikr, 1986), 243-244. Lihat juga, Abdul Wahab Khalaf, Ilmu Uṣül al-Fiqh, cet. ke-12 (Kuwait: Dār al-Qalam, 1976), 181.

${ }^{19}$ Muhammad Hashim Kamali, Prinsip dan Teori-Teori Hukum Islam (Usul al-Figh), ter. Noorhaidi (Yogyakarta: Pustaka Pelajar, 1996), 144-5.

${ }^{20}$ Muhammad Abu Zahrah, Ushul Fiqih, ter. Saefullah Ma'sum (Jakarta: Pustaka Firdaus, 1999), 255-256.

${ }^{21}$ Muhammad Hashim Kamali, Prinsip ..., 148.

22Ibid., 152.; Wahbah al-Zuhaylī, Ușūl ..., 283. 
didefinisikan sebagai permintaan lisan untuk melakukan sesuatu yang keluar dari orang yang kedudukannya lebih tinggi kepada orang yang kedudukannya lebih rendah. ${ }^{23}$ Menurut pendapat jumhur, perintah itu sendiri, apabila tidak disertai dengan petunjuk-petunjuk atau kejelasan yang memberinya makna khusus, menyatakan kewajiban atau hanya permintaan yang tegas. Tetapi hal tersebut dapat berubah apabila ada petunjukpetunjuk lain yang dapat menarik perintah kepada mubah, sunah bahkan variasi makna lainnya. ${ }^{24}$

Metode kedua, yakni metode kausasi merupakan metode penemuan hukum yang penting karena berupaya mengkonstruksi hukum terhadap kasus-kasus yang tidak ada teks hukumnya. Metode kausasi berupaya untuk menyelidiki pondasi yang menjadi dasar tegaknya hukum Islam. Dalam hal ini, metode kausasi ini kemudian dikategorikan menjadi dua model, yaitu yang mendasari adanya hukum pada 'illat, dan yang mendasari adanya hukum pada maqāsid al-shari'ah. Metode kausasi berusaha melakukan penggalian causa legis dari hukum kasus pararel untuk diterapkan kepada kasus serupa yang baru. Apa yang dilakukan hakim atau ahli hukum di sini adalah binä' albukm 'ala al-illah (pendasaran hukum kepada causa legis). Apabila tidak ada kasus paralel, maka pendasaran hukum kepada causa legis tidak dapat dilakukan. Oleh karena itu penemuan hukum dapat dilakukan dengan pendasaran hukum kepada causa finalis hukum, yaitu maqāṣid al-sharīah. Dengan kata lain, dilakukan ta'līl al-ạ̣kēm bi maqüsid al-sharìah. 25

Model pertama, yaitu yang mendasari adanya hukum pada 'illat biasanya juga disebut dengan qiyas (analogi). Qiyas seringkali didefinisikan dengan menerangkan hukum sesuatu yang tidak ada nās-nya dengan sesuatu hukum yang ada nash-nya, dengan asumsi adanya persamaan illat. ${ }^{26}$ Dalam hal ini, qiyas memiliki empat unsur pokok yaitu: (1) kasus baru (far) yang membutuhkan solusi hukum; (2) kasus asli (asl) yang ada dalam sumber-sumber asli al-Qur'an, sunah dan konsensus; (3) alasan,

\footnotetext{
23Wạ̣bah al-Zuhaylī, Ușūl ..., 218.

${ }^{24}$ Muhammad Hashim Kamali, Prinsip ..., 180.

${ }^{25}$ Syamsul Anwar, "Argumen ..., 45.

${ }^{26}$ Abdul Wahab Khalaf, Imu ...,52.
} 
ratio legis ("llah), sifat umum yang ada pada kasus baru dan kasus asli; dan (4) norma hukum (buk.m) yang dinisbatkan kepada kasus baru dan karena kesamaan antara dua kasus, yang ditransfer dari kasus lama ke kasus baru. ${ }^{27}$

Model kedua, yaitu yang mendasari adanya hukum pada maqāsid al-sharīah. Model ini bermaksud mencapai, menjamin, dan melestarikan kemaslahatan bagi umat manusia. ${ }^{28}$ Untuk memenuhi harapan tersebut, kemudian disusun prioritas yang berbeda namun saling melengkapai, yaitu: al-darüriyyät, al-häjizyāt dan al-tabsiniyät. Al-darüriyyāt merupakan aspek kepentingan primer yang ketiadaannya dapat merusak kehidupan manusia. Paling tidak ada lima aspek kepentingan yang harus dilindungi, yaitu: agama, jiwa, akal, keturunan, dan harta. ${ }^{29}$ Adapun al-häjiyāt merupakan kebutuhan sekunder, yaitu sesuatu yang dibutuhkan oleh manusia untuk mencapai kepentingan-kepentingan yang termasuk dalam aspek al-darüriyyät. Sedangkan al-tabsiniyāt merupakan kebutuhan tertier yaitu sesuatu yang kehadirannya bukan niscaya maupun dibutuhkan, tetapi bersifat memperindah proses perwujudan kepentingan al-darüriyyät dan al-häjiyaät..$^{30}$

Metode ketiga, penyelarasan, yakni metode yang berupaya menyelaraskan berbagai dalil hukum yang mungkin secara zabir bertentangan satu sama lain. Untuk itu, dalam metode penyelarasan kemudian dikembangkan teori nasakh dan tarjīh. Secara sederhana, nasakh merupakan penghapusan atau penggantian suatu ketentuan shariah oleh ketentuan yang lain dengan syarat bahwa yang disebut terakhir muncul belakangan dan kedua ketentuan itu ditetapkan secara terpisah. ${ }^{31}$ Adapun tarjih merupakan metode yang digunakan bila muncul dua naș yang secara zahir yang saling bertentangan. ${ }^{32}$

${ }^{27}$ Wael B. Hallaq, Sejarah Teori Hukum Islam: Pengantar Untuk Usul Fiqh Mazhab Sunni, ter. E. Kusnadiningrat dan Abdul Haris bin Wahid (Jakarta: RajaGrafindo Persada, 2001), 123.

${ }^{28} Y$ udian W. Aswin, "Maqāṣ̄ìd al-Sharīah sebagai Doktrin dan Metode”, Jurnal Al-Jami’ah IAIN Sunan Kalijaga Yogyakarta. No. 58, tahun 1995, 98.

${ }^{29}$ Waḥbah al-Zuhaylī, Ușūl..., 1020.

${ }^{30}$ Yudian W. Aswin, Maqāsìid ..., 99-100.

${ }^{31}$ Muhammad Hashim Kamali, Prinsip..., 193.

${ }^{32}$ Lebih lanjut mengenai metode ini, lihat, Abdul Wahab Khalaf, 'Ilm Ușūl..., 229-32. 


\section{Metode Penemuan Hukum Islam: Sebuah Catatan}

Dari penjelasan di atas, ditemukan tiga model metode penemuan hukum Islam, yaitu: metode intepretasi linguistik, kausasi, dan penyelarasan. Tiga model ini merupakan metode yang selama ini digunakan oleh para pemikir untuk menemukan konstruksi hukum terhadap suatu kasus yang ada. Tiga model itu memberi petunjuk bahwa hukum dalam Islam hanya dapat dicari dan diderivasi dari teks-teks, yaitu al-Qur'an dan al-Sunnah. Jadi, kecendrungan tekstualitasnya sangat kuat.

Kecendrungan ini dapat dilacak dari konstruksi hukum Islam yang menganggap bahwa hukum tidaklah dibuat, tetapi ditemukan. Menurut Coulson, Tuhan yang merencanakan, namun manusia yang memformulasikannya. ${ }^{33}$ Konstruksi ini merupakan implikasi dari paradigma bahwa hukum Islam merupakan bentuk sapaan (khitäb) Tuhan kepada hamba-Nya.

Dengan adanya pernyataan tersebut, persoalan hukum Islam akan memiliki problem serius, yaitu bahwa hukum Islam seringkali berupaya menciptakan law in book dan menafikan law in action. ${ }^{34}$ Akibatnya, pada tataran empiris, sebuah teori yang diidealkan seringkali tidak berfungsi atau pun gagal pada tingkat aplikasinya. Hal inilah yang mendorong Coulson menjelaskan adanya konflik dan ketegangan yang bersumber dari teori dan praktek dalam hukum Islam. ${ }^{35}$ Walaupun rumusan Coulson mendapatkan kritik begitu tajam dari Muslehuddin, ${ }^{36}$ namun dalam kenyataannya, konflik antara idealisme dan realisme hukum Islam dapat dirasakan dengan nyata di hadapan kita.

Metode penemuan hukum yang sangat tekstual, tidak lahir secara kebetulan saja. Sebaliknya, hal tersebut muncul sebagai

${ }^{33}$ Noel J. Coulson, Konflik ..., 2.

${ }^{34}$ Menurut Anwar, ada lima karakteristik epistemik kajian fiqh, salah satunya adalah pemusatan pada studi hukum Islam sebagai law in book, tidak mencangkup law in action. Lihat juga, Syamsul Anwar, "Paradigma Fikih Kontemporer: Mencari Arah Baru Telaah Hukum Islam”, dalam Syamsul Anwar, Metodologi Hukum Islam (Kumpulan makalah tidak diterbitkan), 9.

35J. Coulson, Konflik ..., 71-94.

36Lihat, Muhammad Muslehuddin, Filsafat Hukum Islam dan Pemikiran Orientalis: Studi Perbandingan Sistem Hukum Islam, ter. Yudian Wahyudi Asmin (Yogyakarta: Tiara Wacana, 1997), 166-78. 
karakter dari satu epistemologi, bahkan pandangan hidup (weltanschaunng) tertentu. Dominasi nalar bayani sangat tampak dalam spektrum sejarah pemikiran hukum Islam. Walaupun beberapa ulama telah mencoba melakukan terobosan dengan merumuskan paradigma baru, namun sangat jelas, masih adanya nuansa tekstualitas yang sangat kental dan sulit ditinggalkan. Mahmud Muhammad Taha misalnya, berusaha merumuskan metode yang menggabungkan nalar bayāni dan 'irfäni ${ }^{37}$ namun tetap saja dominasi teks masih begitu kentara. Fazlur Rahman dan Syahrur pun demikian, berpendapat hukum Islam nampak masih memusatkan pada analisis normatif-tekstual. ${ }^{38}$

Untuk menjembatani adanya ketimpangan antara tekstualitas dengan dimensi sosial empiris, dan untuk menyelesaikan krisis epistemik kajian figh yang terasa menafikan law in action, maka harus dicarikan metode penemuan hukum yang lebih tepat dan memadai. Sebuah konstruksi metode penemuan hukum yang tidak hanya menekankan pada analisis normatif-tekstual dan meniadakan analisis sosial-empiris. Adanya kecenderungan untuk tidak terlalu berlebihan pada analisis sosial-empiris dan menafikan analisis normatif-tekstual.

Tawaran yang perlu mendapatkan perhatian datang dari Louay Safi, metode penemuan hukum “terpadu". Metode ini menggabungkan analisis normatif-tekstual dengan sosial-empiris. Kerangka dasar metode itu berpijak pada dua prosedur, yakni inferensi tekstual dan inferensi historis. Adapun langkah prosedur tersebut dapat dijelaskan sebagai berikut:

Pertama, prosedur inferensi tekstual. Prosedur ini dimaksudkan aturan dan konsep dari wahyu secara sistematis. Adapun langkah-langkah yang harus dilalui dalam prosedur ini adalah sebagai berikut:

1. Mengidentifikasi seluruh pernyataan baik dari al-Qur'an maupun Nabi yang relevan dengan pertanyaan yang sedang

${ }^{37}$ Agus Moh. Najib, "Kecendrungan 'Irfani dalam Hukum Islam: Pemikiran Mahmud Muhammad Taha" dalam M. Amin Abdullah dkk, Antologi Studi Islam: Teori dan Metodologi (Yogyakarta: Sunan Kalijaga Press, 2000), 314.

${ }^{38}$ Mengenai analisis terhadap pemikiran Rahman dan Syahrur, lihat, Wael B. Hallaq, Sejarah..., 357-88. 
dibahas. Identifikasi itu bukanlah suatu prosedur mekanik semata, tetapi mencakup pula analisis dan pendalaman terhadap pemakaian linguistik.

2. Memahami makna pernyataan al-Qur'an yang relevan, secara individual dan dalam kaitannya dengan yang lain. Dalam hal ini, pernyataan al-Qur'an tidak dapat dipahami semata-mata dengan menganalisis penggunaan leksikal terhadap termaterma individual. Setiap pernyataan itu harus ditempatkan dalam tiga konteks yang saling terkait: konteks tekstual, konteks wacana dan konteks eksistensi.

3. Berkaitan dengan ta'lïl terhadap teks, yaitu causa efficien yang menjadi dasar adanya perintah atau petunjuk, mengidentifikasi sifat umum yang dimiliki oleh objek yang berbeda-beda, yang menjustifikasi acuan penggunaan terma yang sama. Pengidentifikasian 'illat suatu aturan merupakan langkah pertama dalam upaya menemukan prinsip-prinsip universal yang mengatur berbagai pernyataan shariah.

4. Membawa kesatuan dan keteraturan ke dalam berbagai aturan dan prinsip yang diderivasikan dari teks wahyu. Ini berarti bahwa berbagai aturan perlu dibangun ke dalam suatu sistem yang komprehensif dan konsisten secara internal melalui proses abstraksi yang terus menerus, kemudian ia dimasukkan ke dalam serangkaian aturan lain yang memiliki tingkat abstraksi yang lebih tinggi. ${ }^{39}$

Kedua, prosedur inferensi historis. Prosedur ini dilakukan melalui empat langkah, berikut adalah tahapan-tahapannya:

a) Menganalisis aksi individu yang termasuk ke dalam fenomena sosial yang sedang dibahas sehingga diketahui tiga faktor determinan, yaitu tujuan, motif, dan aturan. Tujuan merupakan seluruh obyek yang dikemukakan aktor untuk diwujudkan; motif adalah dorongan psikologis aktor atau motivasi untuk berbuat dari komitmen kepada suatu prinsip moral atau dari kepentingan diri; aturan merupakan prosedur teknis yang harus diikuti aktor untuk mencapai tujuan perbuatannya. Klasifikasi berbagai mode atau tipe aksi berdasarkan pada kesamaan atau perbuatan komponen. Aksi

${ }^{39}$ Louay Safi, Ancangan ..., 217-23. 
yang mempunyai tujuan sama, membentuk suatu kelompok yang homogen, sementara aksi yang memiliki tujuan berbeda membagi populasi dalam kelompok heterogen.

b) Upaya-upaya untuk megindentifikasi aturan-aturan universal yang membangun interaksi antara berbagai kelompok yang diidentifikasi dalam langkah kedua. Untuk itu, maka polapola kerjasama dan konflik, dominasi dan submisi, pertumbuhan dan kemuduran, harus dikaji secara komparatif melampaui batasan waktu dan geografis.

c) Aturan-aturan universal yang diperoleh dalam tahap selanjutnya perlu disistematisasikan dalam suatu bentuk yang tidak berbeda dari bentuk yang digunakan dalam derivasi tekstual. Sistematisasi ini dimaksudkan untuk menghilangkan inkonsistensi internal di dalam sistem aturan, baik ang diperoleh dari derivasi historis maupun wahyu. ${ }^{40}$ Aturanaturan inferensi tekstual dan inferensi historis menunjukkan pada pola-pola general inferensi ilmiah yang digunakan dalam dua pendekatan itu. Dari dua model inferensi itu lalu merujuk pada pola inferensi terpadu. Pola general inferensi terpadu dapat dilakukan melalui prosedur sebagai berikut:

- Analisis teks atau fenomena ke dalam komponenkomponen dasarnya, yaitu pernyataan atau aksi.

- Pengelompokan pernyataan atau aksi yang sama di bawah satu kategori

- Mengidentifikasi aturan-aturan yang menyatukan berbagai kategori.

- Identifikasi aturan-aturan dan tujuan-tujuan general yang membangun interaksi atau inter-relasi berbagai kategori.

- Sistematisasi aturan-aturan yang diperoleh dari prosedurprosedur sebelumnya (menghilangkan kontradiksi). ${ }^{41}$

Dengan tawarannya mengenai model penemuan hukum terpadu ini, Safi tampaknya berusaha menyejajarkan pentingnya telaah normatif-tekstual dengan telaah sosial-empiris. Dengan demikian, konstruksi hukum yang muncul lebih mampu diaplikasikan dalam ranah realitas.

${ }^{40}$ Ibid., 223-7.

${ }^{41}$ Ibid., 227. 


\section{Catatan Akhir}

Hukum merupakan sesuatu yang harus dicari sekaligus ditemukan kembali, demi asas manfaat dalam kehidupan beragama manusia. Hukum Islam merupakan "pemberian" dari Allah yang harus dilestarikan dalam formulasi baru sesuai dengan konteks zaman dan tempat di mana masyarakat berinterkasi. Tawaran Safi tentang metode penemuan hukum "terpadu" sangat menarik untuk dicermati. Akan tetapi, tawaran tersebut tidak menutup kemungkinan muncul model-model lain yang lebih baik lagi. Dengan demikian, Tawaran Safi, bisa menjadi model sebuah penemuan hukum yang berorientasi pada perpaduan antara analisis teks (normatif-tekstual) dan konteks (sosial-empiris). Sebuah model yang membuat hukum Islam tidak kehilangan relevansinya dalam konteks masyarakat kontemporer dewasa ini. Umat Islam, tentu tidak mau dikatakan hukumnya (baca: shari'ab) tidak mampu menjawab tantangan zaman. Oleh sebab itu, perlu adanya kreasi yang terus menurus dari para akademisi dan cendikiawan muslim yang peduli dengan agamanya. Wa al-Lāh a lam bi al-shawäb.

\section{Daftar Pustaka}

Anwar, Syamsul. 2000. "Teori Konformitas dalam Metode Penemuan Hukum Islam al-Gazali" dalam M. Amin Abdullah dkk, Antologi Studi Islam: Teori dan Metodologi. Yogyakarta: Sunan Kalijaga Press. . "Argumen A Fostiori dalam Metode Penemuan Hukum Islam" dalam Syamsul Anwar, Metodologi Hukum Islam (Kumpulan makalah tidak diterbitkan).

."Epistemologi Hukum Islam", dalam Syamsul Anwar, Metodologi Hukum Islam (Kumpulan makalah tidak diterbitkan).

. "Paradigma Fikih Kontemporer: Mencari Arah Baru Telaah Hukum Islam", dalam Syamsul Anwar, Metodologi Hukum Islam (Kumpulan makalah tidak diterbitkan). 
Aswin, Yudian W. 1995. Maqasid al-Shariah sebagai Doktrin dan Metode, dalam Jurnal Al-Jami'ah IAIN Sunan Kalijaga. Yogyakarta. No. 58.

Coulson, Noel J. 2001. Konflik dalam Yurisprudensi Islam, ter. Fuad. Yogyakarta: Navila.

Hallaq, Wael B. 2001. Sejarah Teori Hukum Islam: Pengantar untuk Ușül Fiqh Mą̧ab Sunni, ter. E. Kusnadiningrat dan Abdul Haris bin Wahid. Jakarta: RajaGrafindo Persada.

Iqbal, Muhammad. 1983. Pembangunan Kembali Alam pikiran Islam, ter. Osman Raliby. Jakarta: Bulan Bintang.

Kamali, Muhammad Hashim. 1996. Prinsip dan Teori-Teori Hukum Islam (Ușūl al-Fiqh), ter. Noorhaidi. Yogyakarta: Pustaka Pelajar.

Kansil, C.S.T. 1989. Pengantar Ilmu Hukum dan Tata Hukum Indonesia. Jakarta: Balai Pustaka.

Khalaf, Abdul Wahab. 1976. Ilmu Ușūl Fiqh, cet. ke-12. Kuwait: Dār al-Qalam.

Muslehuddin, Muhammad. 1997. Filsafat Hukum Islam dan Pemikiran Orientalis: Studi Perbandingan Sistem Hukum Islam, ter. Yudian Wahyudi Asmin. Yogyakarta: Tiara Wacana.

Najib, Agus Moh. 2000. "Kecendrungan Irfani dalam Hukum Islam: Pemikiran Mahmud Muhammad Taha" dalam M. Amin Abdullah, dkk. Antologi Studi Islam: Teori dan Metodologi. Yogyakarta: Sunan Kalijaga Press.

Safi, Louay. 2001. Ancangan Metodologi Alternatif: Sebuab Refleksi Perbandingan Metode Penelitian Islam dan Barat, ter. Imam Khoiri. Yogyakarta: Tiara Wacana.

Schacht, Josept. 1971. An Introduction to Islamic Law. London: Oxford University Press.

Zahrah, Muhammad Abu. 1999. Ushul Fiqh, ter. Saefullah Ma'sum. Jakarta: Pustaka Firdaus.

al-Zuhayli, Wahbah. 1986. Ușūl al-Fiqh al- Islämi, cet.ke-1. Damaskus: Dār al-Fikr. 